\title{
Characterizing preservice Teacher's responses to literacy: Read alouds a way to experience the joy for reading*
}

Judith Castellanos

\begin{abstract}
This article reports on a small-scale project which central purpose was to incorporate read-alouds in a pre-intermediate English as a foreign language class of preservice teachers during three weeks. Students responded orally and in a written way on their journals to these readings showing understanding of the texts, relating their personal experiences and / or making connections to them. The project involved students of the undergraduate program in English teaching at Universidad Distrital Francisco José de Caldas, Bogotá. In all, 19 students were involved in the project. Data collection sources for this project include students' journals, after the fact notes on students' oral interactions and a group interview. Among the findings observed in this inquiry project include the intertextual connections (Short, 1993) students make across the texts read in class with their personal experiences. Most students' oral responses were characterized by code-switching; in general most students code switched depending on the difficulty of the answer. Students benefited from the readingalouds in terms of opportunities to interact among themselves, practice their oral and written skills, and enjoy the pleasures of reading, thus building ground to a positive experience that may be emulated in their future teaching exercise. Finally, I discuss some implications of read-alouds with preservice teachers and teacher education programs in Colombia.
\end{abstract}

Key words: read-alouds, preservice teachers, reader's response, journal writing

\section{Resumen}

El siguiente artículo es un reporte de un proyecto de clase cuyo objetivo central fue la incorporación de lecturas de cuentos en un curso pre-intermedio de Inglés, con estudiantes de licenciatura en Inglés durante tres semanas. Los estudiantes respondían en forma oral o escrita en sus diarios a las lecturas de los cuentos exponiendo lo comprendido o realizando conexiones con sus experiencias personales. El proyecto se llevó a cabo con estudiantes de "Licenciatura en Educación Básica con Énfasis en Inglés como Lengua Extranjera" de la Universidad Distrital Francisco José de Caldas, Bogotá. En total, 19 estudiantes formaron parte del proyecto. Los instrumentos para la recolección de datos que se utilizaron incluyen los diarios de los estudiantes, notas sobre su interacción oral y una entrevista grupal. Los resultados que se observaron se encuentran las conexiones intertextuales (Short, 1993) que los estudiantes hacen entre los textos leídos y sus experiencias personales. La mayoría de las respuestas orales de los estudiantes se caracterizaban por el cambio de un código a otro; por ejemplo, de Inglés a Español y viceversa ; dependiendo de la dificultad de la respuesta. Los estudiantes se beneficiaron de las lecturas de cuentos en voz alta ya que tuvieron oportunidad de interactuar entre ellos, poner en práctica su habilidad oral y escrita y disfrutar los placeres de la lectura, viviendo una experiencia positiva que podrían eventualmente imitar en un futuro como docentes. Finalmente, se discuten algunas implicaciones que tiene esta práctica para los estudiantes de licenciatura y para los programas de educación para docentes en Colombia.

Palabras claves: lectura en voz alta, maestros en formación, respuesta de los lectores a textos escritos, escritura de diarios.

* Received: 03-03-2004 / Accepted: 20-08-2004 


\section{Introduction}

As a teacher educator and a student of the Masters program in Applied Linguistics in ELT, I had the opportunity to learn about read-alouds during a Seminar on Literacy. In my interest to give my first steps as a novice researcher, I wanted to explore read-alouds with second semester students of EFL who are enrolled in a preservice program. These particular students are in the beginning of their process of learning English and are expected to achieve a considerable mastery of the language in all the skills by sixth semester when they begin their practicum. The need for providing these students with opportunities to learn the language encouraged me to observe whether read-alouds have a role in such learning process. Since the class that was subject of this project was mixed-ability, some students were L2 struggling readers while others did not experience much difficulty in reading texts suitable for their own level. Therefore, experiencing meaningful reading for the former students was really limited while the later had a more ample comprehension lens. Sensing such situation, I decided to explore with read-alouds in order to give all students fair and equal opportunities for oral and written production by responding to literature, especially children's books.

The purpose of this article is to share with other novice researchers, teacher educators and language teachers in general, my experience with this small scale project. It is also an invitation to language teachers to reflect upon the various possibilities to enrich our classes by incorporating flexible innovations for promoting language improvement in our students.

\section{Literature Review}

Dewey (1938) states that learning is a social process and that we make decisions on what to learn or teach, depending on the purpose or need of certain knowledge in time. My point of departure for this inquiry project was the assumption that my participants, who are at their initial stage of a literacy process in EFL, would profit from read-alouds which emphasize on a social aspect of reading: building a community of listeners around a reading event. As a community of listeners, students actively engage in the story by interpreting it and relating it to lived experiences of their own and of others. Dewey (1938) says that our life experiences will shape our capabilities and abilities according to the social context we move in and our own individual characteristics. This 
social characteristic of learning can be experienced by means of read-aloud events.

\section{Read-alouds}

Read-alouds are widely used as a way to introduce students to the pleasures of reading and books. A practice usually associated with teaching children, can also be used to introduce young adults, who are beginning to learn a new language, to the pleasures of reading. Teachers may differ in their specific read-aloud styles; however, these events usually conclude by providing students a time and space for class discussions about the story. These after reading discussions provide opportunity for students to connect the story to their personal lives and for teachers to explore the connections that students have made (Peterson E Eeds, 1990, cited in Barrentine, 1996). First, "After-reading" discussions which are reflective and aim to deepen, broaden, and personalize story meaning, (Barrentine, 1996) is an important concept for this project since I aimed at observing students' oral responses to stories read in class. Second, this inquiry is based on the concept that comes from the transactional theory of literary reading, known also as reader response (Rosenblatt, 1978, cited in Dugan, 1997). According to this theory readers actively construct meaning by responding to and reflecting on a text. In Rosenblatt's words (1978, 1982 cited in Dugan, 1997), students explore both aesthetic and efferent stances ; an aesthetic stance by reading to experience the poem, the play or the story, or an efferent stance by reading to gather information. As Rossenblatt (1982, cited in Dugan, 1997)) suggests, it's crucial that all students, including struggling readers, have opportunities to respond aesthetically to foster appreciation as well as a lifelong desire to read.

\section{Journal writing}

The journal is a place where our thinking can become visible, a place where we toss around ideas, consider what others think, make connections between new and prior information, examine our own thinking strategies, and judge our own learning (Wilcox, 1998). Wilcox presents a taxonomy of thinking journals according to content and language of thinking ; from her taxonomy the responder journal keeper contents include interpretations, reactions, questions, comments and through them he/she illustrates, expresses, describes, selects, 
justifies, deduces, supposes and sorts. Bearing this definition in mind, readalouds provide opportunities for students to write in response to the readings. This project builds on evidence suggesting that responding to reading in writing, sharing ideas and reflecting on our own ways of knowing are processes that enhance learning and improve thinking (Wilcox, 1998). Students' personal responses and reflection were recorded in their journals.

\section{Read-aloud events}

I wanted to engage students in read-aloud events by following a four-stage methodology I name getting ready, reading aloud, students' oral response, and journal writing. Following I explain every step in the methodology:

\section{Getting ready}

These events occur before students are exposed to the text and involve drawing from students' background about the type of story (a fable, a poem, a children story, folk tales, etc. In this way, students are prepared for the type, structure and organization of the text they will be exposed to. In terms of content, these students usually draw from previous experiences they have had with stories. These students may have an advantage in this process in terms of their age, experience, mastery of L1 and knowledge of the world. Also, this may be manifested if students have read the story before or if they are somehow familiar with it because they are part of the common knowledge even though they have not read it themselves. This type of knowledge usually happens with fables and children stories that are widely published, put into cartoons, films or children's' TV shows. Furthermore, getting ready also means that the teacher builds interest by showing them titles, book covers, and illustrations to make predictions. These predictions are then validated, confirmed or rejected through the reading. This particular event prepares student to make sense of texts. According to Goodman (1996) the ability to make sense is always limited by how much we already know about what we are reading. When we construct meaning from reading, we must draw on what we know, what we believe and what we value. Moreover, making sense of the text involves three participants: students, teachers and the text. Goodman (1996) also says that the more we know about what we are reading, the easier it will be to read, and what a reader knows and believes will strongly influence the meaning he or 
she constructs. The role of the teacher in the reading-alouds with these types of students is particularly important due to students' own literacy needs as readers and writers of a foreign language. Therefore, developing background and drawing from what the students know will prepare them to face the texts and help them get the most from them.

\section{Reading aloud events.}

These events happen when the teacher reads to students, providing a model for reading, incorporating sounds, gestures, stopping at specific points to focus attention on actions and / or illustrations. Teachers should play the role of readers if we want students to become readers. Then, a teacher should model the typical behaviors of a reader in the classroom, or as $\operatorname{Lerner}^{2}(2001,153)$ states: "the teacher's reading is particularly important during the first stages of schooling, when the children can't read by themselves". The subject students of this particular project are not children but are beginning a literacy process in a foreign language, English. Moreover, it is also important to take into account that they will become children teachers and by exposing them to these experiences will give them ideas of how to approach the teaching of English to children. The main question of this inquiry project seeks for answers on how reading-alouds help students' oral and written communication, which involves the purpose of creating a proper environment for reading in the classroom where teachers can play the role of interpreters so the students can read through them $\left(\right.$ Lerner $\left.^{3}, 2001\right)$.

\section{Students' oral responses.}

After reading, discussions provide opportunities to "trace" ideas that were significant (Smith, 1990 cited in Barrentine, 1996), make connections to personal experiences, discuss elements of the story and elements of literature.

\section{Journal writing.}

This is a writing activity that follows group discussions which had an optional nature, that is to say, students exercised their own choice to whether or not respond to the read-aloud in their journals. This type of thinking on paper is an individual activity at home. Students choose some aspect, theme or interpreta-

\footnotetext{
The translation is done by the author.

The translation is done by the author.
} 
tion of the story read by the teacher to reflect on further in their journals. These journals primary purpose is to become a space for students to explore and extend ideas; therefore, content is what matters and not a focus on grammar and mechanics of the language used. Journals were occasionally responded to in writing to offer the students feedback, praise them for their compositions, raise a question or make suggestions. In order to make journal writing more meaningful students were given opportunities to share their journals with their classmates. This made them feel proud of their work, exchange ideas or simply share their insights. As Dewey (1938) states, learning is a social experience, and students' interactions and discussions with their classmates and journal entries about their responses to pieces of literature provides them with a supportive environment to learn. Short (1993) argues that "for all learners the best most productive learning situation is the one in which we keep within sight what we already know as we push into new territory". Here she is addressing Vigotsky's (as cited by Short, 1993) zone of optimal learning which means that we are able to learn with the support of others not forgetting what we already are able to do alone.

\section{The Project}

\section{Participants}

Nineteen EFL students from a public university from Bogotá participated in the project. Six male students (age range from 16 to 23, average age 18) and thirteen female students (age range from 16 to 23, average age 18) were the participants. This small-scale project on the subject of read-alouds has as participants second semester students of the undergraduate program in English teaching at Universidad Distrital Francisco José de Caldas, Bogotá. The students were in their second semester of English, comparable to a preintermediate level of English, and attended ten hours of English a week, two hours daily. Some of them had only been exposed to two hours of English a week in high school before starting their first semester in the undergraduate program, while others had attended extra curricular English courses. During their first semester they had ten hours of English instruction a week, distributed in two hours of class daily. As a result of the students' previous experiences with learning the language, they comprised a mixed-ability class. 


\section{Data collection and analysis}

Students were invited to take part in this inquiry project as part of the regular English classes. All students agreed to participate in the project and I obtained oral permission to use the data. Their anonymity was guaranteed for publication of results. During a period of three weeks, data were collected through "after the fact" field notes of students' oral responses to read-alouds, students' journal and a group interview in Spanish that was conducted by the end of the second week of the project in which seven students participated voluntarily. The interview was recorded and transcribed. The words from student 1, 2, 3 and so forth were used instead of the students' real names.

Data analysis consisted of examining the data carefully to search for salient patterns, and emerging commonalties were used to construct the final categories. Special attention was paid to the oral and written responses of the participants to the literature read during the three weeks of the project that revealed opportunities to improve language production. The strategies for data analysis presented by Hubbard and Miller (1993) and the grounded data analysis approach (Freeman, 1998) were used to construct the categories. Data extracts taken form the journals and the interview transcripts are used to provide evidence and reveal the participant's perspective.

\section{Findings}

As described in the following sections, data analysis revealed that students experienced gains from read-alouds in developing a sense of agency in the learning process. It has also shown that students made intertextual relations when they were engaged in the after reading discussions and writing in their journal and finally code-switching as a mechanism for oral after reading discussions.

\section{Developing a sense of agency in the learning process.}

The read-alouds acted as motivation for students to become self-directed and developed a sense of agency in their learning process in regards to the class. Concerning this sense of agency, some of the students expressed the following:

S1: (...) I think it should be more interactive, for instance a day before some books are brought and given to the students, in order, or well, at random. A 
student is chosen and he/she prepares the reading, the pronunciation and then the next day he/she shows up and presents it (the book). It could help for his/her own speaking and also ours.

S2 : (...) I think S1's idea is very good, it is like getting ourselves involved. Because ...., obviously, the teacher comes and reads to us and we pay attention to the illustrations too, "oh, look it's a...", "and this means..." But it would also be very important to get involved, that we come and take over the class because it's ours, then, Laura did it, then Pedro, then another one, did his/her class, he/she understood, we understood and we practiced more.

(Group interview, Spanish, the translation is done by the author)

Here, $\mathrm{S} 1$ addresses a positive impact that becoming the reader would have in their reading aloud skills (pace, tone, pronunciation, etc.) but he also implies that students should present the books they have read to the whole class. Later on he adds that becoming the reader would also help them lose fear before an audience and be more confident as English user and that students shouldn't only read but also prepare an oral presentation based on the book. Another student, S2, agrees with S1's idea of becoming readers and emphasizes on the idea of "taking over the class" as a way to feel that the class belongs to them. Such practice means putting the curricula in the students' hands, which is an important characteristic in education nowadays. The students' voices were heard and the change they proposed was incorporated. They were given the chance to choose a book and share it with their classmates in small groups during the third and last week of this project; they became the readers. The following journal entry of one of the students shows how such turn in the readalouds benefited him:

May $16^{\text {th }}, 2003$

\section{Reading in Groups}

This is an interesting activity, because we need to pay attention in our partners' reading style. In my case, I need a lot of work in this, I need to read as I do in Spanish, fluently and faster. But this is the beginning of this process so in vacation when I buy and E-E dictionary ${ }^{3}$, I'll try to get vocabulary with its correct pronunciation.

In the following dialogues from the interview, students talk about their feelings and thoughts toward read-alouds:-

3 The student wrote E-E dictionary meaning English-English dicitonary. 
Teacher: The first thing I want to know is your opinion about the readingalouds done in class.

S1:I think they are good because we are developing more listening and we pay attention to the word we don't understand, I mean, if we don't understand it, we look it up in the dictionary and that way we improve our vocabulary.

Teacher: That's to say when the teacher is reading you practice your listening skills, right?

S2: I think it's very good! because, for instance, you can get the general idea, maybe you don't understand a sentence you get lost but then if you look at the drawings you start getting the story and listening, then you get the general idea and it doesn't matter if you didn't get a sentence or if you don't know a word, because you get the meaning, what the book is about.

Teacher: Was it motivating to listen to stories read by the teacher?

S4: It is also motivating for me because it's something new for us, it's not only asking the student who knows more or the one who is closer, what does that mean? No, you look up words in a dictionary, then I think we are being really motivated

S2: I see it motivating in that sense, because we understand more, we get it, we pay more attention, it's cool because it's different to the same bla, bla, bla, but instead, this is something new to us and as future teachers, we can do these things, I mean, if we see that this works for us, we can take them into account to help children.

Teacher: How about enjoyment? relaxation? What happens during the readings?

S5: $\quad$ Personally, when there are readings, even though it doesn't seem like it, I enjoy them a lot, I mean it's cool, because ... (laughs), yeah, I enjoy within, because besides learning for myself, you are learning to transmit knowledge, then you kill two birds in one shot, you are happy and learn to give, right? That's why I say this is good, that's why I enjoy it.

Teacher: But, anyway, what is the joy?

S5: $\quad$ To me the joy consists on that every reading brings something new, there are words, expressions, o some type of time tense, or cultural expressions, and I know that by reading something will be learnt and that I won't forget, and you enjoy even more when you use what you know and you apply it in a correct way. That's the joy for me.

(Interview, Spanish. The translation is done by the author) 
The voices of these students convey powerful messages. Beyond enjoyment and motivation, reading aloud activities helped them develop positive attitudes toward the language learning, they experienced improvement in their own learning process, as well as experiencing new ways to learn the language; an experience they also see as something they can transfer, that's to say, apply activities of the sort when they become teachers.

\section{Intertextual connections}

Keeping in mind the question of how read-alouds enhance students' oral and written production, let us turn to what Short (1993) describes as intertextual connections. They refer to the kind of connections students make across the texts read in class with their experiences. Orally, students referred to characters, plot elements and even illustrations, they also connected the topic of the story to real life situations ; meanwhile, their journal entries showed connections of topics with personal opinions, past or present experiences. During an "After reading" discussion I asked the students to comment on the story in pairs or small groups. For 5 minutes they interacted, some in English and code-switching to Spanish when they didn't know how to say something. Here is an extract from the whole - group discussion:

T: $\quad$ Now that you discussed in groups. Who would like to comment on the story?

S1: It's about how parents always want the better [sic] for the children.

S2: We always think that the better is always something or somebody greatest.

S3: La gente no se valora a si mismos, piensan que tienen muy poquito que ofrecer a otros, o por el contrario, piensan que son lo mejor y son sabelotodos.

(People don't value themselves, they think they have very little to offer or other people, or on the contrary, think they are the best and know-it-all.)

S4: It's about a father who wants the best for his daughter.

Through this type of interactions, students summarized the plot, made connections with parents - children relationships and people personalities. Students heard each other's ideas and those who had not reflected on the story now had an opportunity to do it. Listeners also had opportunities to reflect 
upon the story since they had others' ideas to build on, disagree or agree with. We ended up the interaction and I invited students to respond to the story in their journals. They were to do so individually and during off-class time. The following is a continuation of one of the student's journal entry cited above :

May $16^{\text {th }}, 2003$

Now I'm reading your little book, it's very delicious [sic] to read, it's so simple and easy to understand, it's got a lot of beautiful messages of a real friendship ; there's one special reading, it talks about the two miners in New Mexico, how a man can risk his life for a friend; this reading remind(s) me how the greatest man on all earth gave his life for all of us; he only wanted that we can be free, he wanted to erase all sins in us. It's our loved Jesus Christ. The greatest man from the beginning of time to the end of these. So I'm copying in a notebook all of these short poems, that's great for my n' for my learning process, get the more vocabulary I can.

This student's reflection shows in Short's (1993) words intertextual connections (responses to characters, plot elements, connections to the topic of the story to real life situations), or in Rosenblatt's (1982) words, he explores aesthetic and efferent stances of reading by including senses, feelings and responses to specific academic concerns; self-reflection, self-reporting and setting learning goals.

Another student writes in her journal:

April $28^{\text {th }}, 2003$

\section{The greatest of all}

This folk-tale of Japan. Tell the story of a mouse that seek a man for husband of his daughter. But he wants the best man of the world. He wents [sic] where the emperator[sic], but he said that the sun was the greatest of all, but he said that the cloud was the greatest of all, but he said that wind was the greatest of all, but he said that (blank) was the greatest of all, but he said that the best husband for his daughter was other mouse. After that, they married and her weeding day went the emperator [sic], the sun, the cloud, the wind and the (blank)

Moral lesson:

The people always seek the greatest of all in bigger things, and never see the things that are in around. And often the best is to our side.

The end.

This student summarizes plot elements and characters, followed by a 
moral lesson. Clearly, she explores an aesthetic stance by inferring the tale's moral in a sentence that conveys a lesson to life.

The following is a poem written by another student and is based on a poem entitled Silence which was a read-aloud event in one of the classes:

My girl is in silence for the lonelyness, [sic]

The lonelyness is in silence for me

The lonelyness is just silence

'cuz I'm alone with my tears.

\section{Code - switching}

During pair or small groups after reading discussions most students' oral responses were characterized by code-switching. Students shared their reactions to the stories in both English and Spanish. According to Auer (1995), the most important of all the definitional criteria for code-alteration is that of its interpretative reality. It is the users of the signs who decide on their status. Having this quote in mind, I observed the code-alteration (Auer, 1995) or codeswitching phenomena from an interpretative approach and not a structural one. I found this an interesting aspect to be explored during the interview and some implied that in general most students code switched depending on the difficulty of the answer, for instance when they were connecting the theme of the reading with personal experiences and wanted to give specific details that demanded a command of English higher to their level. Also, since they were interacting with peers that share the same L1, they may have probably accommodated to the recipient's language preference (Auer, 1995). Conversely, the frequency of code-switching diminished during whole group interactions. This effort of keeping the interaction in the L2 could mean that the speaker is complying with the community norms for language choice (Auer, 1995). In that particular type of interaction, the speakers were interacting with the teacher by sharing their ideas, feelings and thoughts about the story read. I concluded that such phenomenon was encouraged by the fact that they were addressing the teacher of the L2, who represents the norm for language choice. Students really made an effort to give their responses in English, occasionally appealing to some compensatory strategies (Dörney, 1995: 58, cited in Brown, 2000) such as approximation, nonlinguistic signal (mime, gesture, facial expression, or sound imitation,), foreignizing, code-switching, appeal 
for help, among others.

\section{Conclusions and implications}

The last part of this article presents a summary of the findings of this inquiry project and its implications for EFL contexts and especially the language teaching programs in Colombia. Previously I discussed the reasons that motivated me to incorporate read-alouds in an EFL class of preservice students aiming at providing a learning experience that involves both social and individual experiences. I focused on how read-alouds enhance students' oral and written production by means of their oral interactions and their written responses in their journals.

The interpretive analysis of the data allowed me to conclude that students' oral and written responses were characterized by a sense of agency in their own learning process that they can transfer when they start their teaching practice. Moreover, their responses showed intertextual connections (Short, 1993) and an exploration of an efferent and a aesthetic stance (Rossenblatt, 1978) and finally the role of code-switching in their oral interactions. Students benefited from the reading-alouds in terms of opportunities to interact among themselves, practice their oral and written skills, and enjoy the pleasures of reading, thus building ground to a positive experience that may be emulated in their future teaching exercise.

Having these benefits in mind, educators of preservice teachers should include in their English classes experiences of this kind in order to transcend the structural and grammar-based approaches to teach a language; giving an interesting, stimulating and fruitful turn to language instruction; specially with preservice students who are not only learning a language but also learning from their teachers the nuts and bolts of teaching. Studies in the area of teacher education have suggested that the very first experiences as learners are the ones that preservice teachers and novice teachers draw from to undertake the task of teaching. Second, teacher education programs often focus on the components of language; this narrow view overlooks the social nature of language as a tool for communication and a mechanism through which content can be explored and examined.

The implementation of read-alouds had an impact at the level of an EFL 
classroom of a language teaching program in a public university in Bogotá, Colombia. I hope that the information included here can serve as an inspiring experience for other language teachers in similar contexts who constantly assume the challenge of adjusting and integrating new teaching practices to meet the needs of learners.

\section{REFERENCES}

Auer, P. (1995). The pragmatics of code-switching: a sequential approach. In Leslie Milroy \& Peter Muysken (Eds). One Speaker, Two Languages: Cross-Disciplinary Perspectives on Code-Switching. New York, NY: Cambridge UP.

Barrentine, S. J. (1996). Engaging with reading through interactive read-alouds. The Reading Teacher, 50 (1), 36-46.

Dewey, J. (1938). Experience and Education. New York, NY: Touchstone.

Dugan, J. (1997). Transactional literature discussions: Engaging students in the appreciation and understanding of literature. The Reading Teacher, 51 (2), 86 -96.

Freeman, D. (1998). Doing Teacher Research. Heinle \& Heinle Publishers.

Goodman, k. (1996). On Reading. Portsmouth, NH : Heinemann.

Hubbard, Rand Miller, B. (1993). The Art of Classroom Inquiry: A Handbook for Teacher Researchers. Portsmouth, $\mathrm{NH}$ : Heinemann.

Lerner, D. (2001). Leer y escribir en la escuela: lo real, lo posible y lo necesario. Mexico, DF. Fondo de Culutura Económica, Espacios para la Lectura.

Short, K. G. (1993). Making connections across literature and life. In Holland, KE. et al (Eds). Journeying. Children making responding to literature. Porstmouth, NH: Heinemann

Wilcox, B. L. (Ed)(1998). Thinking journals. The Reading Teacher, 51 (4) 350-353.

\section{Read- Alouds books}

Aardema, V. (1996). The Lonely Lioness. New York, NY : Alfred A. Knopf

Anonimous. The Pied Piper of Hamlin. Bogotá: Panamericana.

Bonsall, C. (1982). The Case of the Dumb Bells. New York, NY: Harper Collins.

Cherry, L. (1993). The Great Kapok Tree. Trumpet Special Edition.

Dakos, K. (1990). If You Are Not Here, Please Raise Your Hand. Poems about School. New York, NY : Aladin pbk.

Exley, H. (Ed.)(1993). Thank Heavens for Friends. New York, NY: Hallmark Books.

Perkins, C (1997). The Yellow Wallpaper and Other Stories. Mineola, NY: Dover Publications Inc. 
Scieska, J. (1991). The Frog Prince Continued. New York, NY: Viking Penguin.

Silverstein, S. (1891). A Light in the Attic. New York, NY: Harper Collins

Wagener, G. (1997). The Ghost in the Classroom. Gossau Zürich, Switzerland :North - South Books. Wilde, O. The Selfish Giant. Bogotá: Panamericana.

THE AUTHOR

Judith Castellanos is a Masters in Applied Linguistics candidate. She is currently working at Universidad Distrital Francisco José de Caldas and Universidad Nacional de Colombia. Also, she is a member of the research group "Lectoescrinautas" recognized by Colciencias.

E-mail: Jucaja_98@yahoo.com 